\section{СMЕРТНАЯ КАЗНЬ \\ В КОНТЕКСТЕ СТАТЬИ 2 ЕВРОПЕЙСКОЙ КОНВЕНЦИИ ПО ЗАЩИТЕ ПРАВ ЧЕЛОВЕКА И ОСНОВНЫХ СВОБОД: ВОПРОСЫ ТОЛКОВАНИЯ}

\section{Аннотация:}

В статье проводится анализ одного из важнейших четырех исключений, предусмотренных статьей 2 Европейской конвенции по защите прав человека и основных свобод, а именно о смертной казни. В настоящее время смертная казнь рассматривается как неприемлемая форма наказания. Однако данный вид наказания существует в 25 странах мира. В 2015 г. были казнены 1634 человека, на 573 человека больше, чем в 2014 г. (не включены данные по Китаю, где информация о смертной казни является государственной тайной). Согласно статье 2 (1) Конвенции, государство-участник может лишить человека жизни посредством смертной казни при условии, что приговор вынесен судом и вынесен только за преступление, караемое смертной казнью. Способ исполнения высшей меры, личные обстоятельства осужденного лица и несоразмерность этой меры с тяжестью совершенного преступления, а также условия, в которых человек находится в ожидании смертной казни, - это некоторые аспекты, по которым обращение с приговоренным к смертной казни или его наказание могут подпадать под действие статьи 3, запрещающей пытки и бесчеловечное или унижающее достоинство обращение или наказание. Взгляды на смертную казнь играют роль при оценке того, был ли превышен допустимый предел страданий или унижения. Автором отмечается ключевая роль следующих дел (постановлений) Европейского суда по правам человека: Оджалана против Турции, Иенса Зеринга против Соединенного Королевства, Ал-Саадона и Муфтхи против Соединенного Королевства, Бадера и Канбора против Швеции, Сельмуани против Франции, Эраи против Турции, Андронику и Константину против Кипра и других. Жалобы, которые были направлены в суд по статье 2, в основном касались причинения смерти в ходе борьбы с терроризмом.

\section{Ключевые слова:}

убийство, наказание, пожизненное лишение свободы, смертная казнь, Европейская конвенция по защите прав человека и основных свобод, право на жизнь, исключение, синдром камеры смертников.

\section{THE DEATH PENALTY IN THE CONTEXT OF ARTICLE 2 OF THE EUROPEAN CONVENTION FOR THE PROTECTION OF HUMAN RIGHTS AND FUNDAMENTAL FREEDOMS: THE ISSUES OF INTERPRETATION}

\begin{abstract}
Summary:
The article analyses one of four pivotal exceptions provided by Article 2 of the European Convention for the Protection of Human Rights and Fundamental Freedoms, namely: the death penalty. Nowadays, the death penalty is regarded as an unacceptable form of punishment. However, this type of punishment exists in 25 countries around the world. In 2015, 1,634 people were executed. This was 573 more than in 2014 (without data on China, where information about the death penalty is confidential). According to Article 2 (1) of the abovementioned Convention, the participating state can deprive a person of life through the death penalty under the stipulation that the sentence is delivered by the court only for those crimes which entail capital punishment. The way of executing such a penalty, the personal circumstances of the convicted person, the disparity between penalty measure and offense severity, as well as the conditions facing by a person on death row are several aspects according to which the treatment of death row prisoners or their punishment are covered by Article 3 prohibiting torture and inhuman or humiliating treatment or punishment. Views on death penalty are important while assessing whether the permissible limit of suffering or humiliation has been exceeded. The author recognizes the crucial role of the following cases (decisions) of the European Court of Human Rights: Öcalan v. Turkey, Jens Soering v. the United Kingdom, Al-Saadoon and Mufdhi v. the United Kingdom, Bader and Kanbor v. Sweden, Selmouni v. France, Ergi v. Turkey and Andronicou and Constantinou v. Cyprus. The complaints addressed to the court under Article 2 focused primarily on causing death in the fight against terrorism.
\end{abstract}

Keywords: murder, punishment, life imprisonment, death penalty, European Convention for the Protection of Human Rights and Fundamental Freedoms, right to life, exception, death row syndrome.

Европейская конвенция предусматривает четыре исключения, которые следует толковать узко, поскольку именно толкование ведет к реальной защите права на жизнь. Первое исключение относится к тому случаю, когда государство сохранило смертную казнь. К сожалению, на сегодняшний день данный вид наказания существует в 25 странах мира, среди которых лидирующими являются Китай, Ирак, Иран, Саудовская Аравия и Соединенные Штаты Америки.

Согласно докладу «Смертные приговоры и казни в 2015 году» [1], опубликованному Amnesty International, в 2015 г. были казнены 1634 человека, на 573 человека больше, чем в 2014 г. В приведенные цифры не включены данные по Китаю, где информация о смертной казни является государственной тайной. 
Согласно статье 2 (1) Конвенции, государство-участник может лишить человека жизни посредством смертной казни при условии, что приговор вынесен судом и вынесен только за преступление, караемое смертной казнью. А для этого должны быть соблюдены статьи 6 и 7 и положения, вытекающие из запрещения дискриминации в статье 14.

Особое значение соблюдения справедливых требований суда было подчеркнуто в решении по делу Öcalan v. Turkey, 46221/99, 12 мая 2005 г. [2]. В данном деле гражданин Турции Абдулла Оджалан до отбывания наказания в виде пожизненного лишения свободы был председателем Рабочей партии Курдистана. 15 февраля 1999 г. по неизвестным причинам был задержан в Кении и далее отправлен обратно в Турцию. Как стало известно, через 4 месяца он был приговорен к высшей мере наказания за отторжение от Турции части ее территории. В 2002 г. Турция отменила в своем законодательстве такой вид наказания, как смертная казнь, и впоследствии смертный приговор был заменен пожизненным лишением свободы. Смертная казнь в отношении Абдуллы Оджалана была заменена пожизненным лишением свободы, в связи с этим нарушение статей 2, 3 и 14 не обнаруживается.

В настоящее время в мире смертная казнь рассматривается как неприемлемая форма наказания, и до сих пор нет данных по вопросу применения смертной казни как бесчеловечного и унижающего достоинство обращения с человеком.

По делу Öcalan v. Turkey, 46221/99, 12 мая 2005 г. [3] суд отметил, что статья 2 исключает применение смертной казни в отношении лица, которому не было обеспечено справедливого судебного разбирательства. Страх и неуверенность в будущем, вызванные смертным приговором, безусловно, причиняют человеку страдания.

Кроме того, даже в тех редких случаях, когда в суд поступали жалобы на осуществление смертной казни в государствах-сторонах, положения статьи 2 (1), разрешающие использование этой меры наказания, не препятствовали рассмотрению судом случаев использования казни с позиций запрета на бесчеловечное и унижающее наказание (статья 3).

Способ исполнения высшей меры, личные обстоятельства осужденного лица и несоразмерность этой меры с тяжестью совершенного преступления, а также условия, в которых человек находится в ожидании смертной казни, - вот лишь несколько аспектов, по которым обращение с приговоренным к смертной казни или его наказание могут подпадать под действие статьи 3. Нынешние взгляды населения договаривающихся государств на смертную казнь играют роль при оценке того, был ли превышен допустимый предел страданий или унижения.

В деле Soering v. the United Kingdom, 14038/88, 7 июля 1989 г. [4] заявитель Йенс Зеринг, гражданин Германии, ссылался на «синдром камеры смертников». После совершения убийства родителей своей супруги он был направлен под стражу в Англию, где впоследствии ждал экстрадиции в Соединенные Штаты Америки. Он опасался того, что по прибытии в данную страну он будет приговорен к смертной казни. У него возникли опасения и страхи по поводу своего будущего.

В науке под «синдромом камеры смертников» понимается такая обстановка, при которой в течение нескольких лет на лиц, приговоренных к смертной казни, оказывается сильное психологическое воздействие, которое разрушает в человеке личность и приводит к ухудшению здоровья.

Суд пришел к выводу, что в случае экстрадиции для Йенса Зеринга существовал риск стать жертвой бесчеловечного и унижающего достоинство обращения, которое нарушает статью 3 Конвенции. К вниманию были приняты особенности его возраста, психологического состояния, личные обстоятельства на момент совершения преступления. Правомерная цель экстрадиции могла быть достигнута другими правомерными средствами, использование которых не приводит к сильнейшим психологическим страданиям.

При оценке того, превышен ли этот предел страданий или унижения, определенную роль играет отношение современного общества договаривающихся государств к смертной казни.

В деле Al-Saadoon и Mufdhi v. the United Kingdom, № 61498/08, 2010 г. [5] жертвами Конвенции стали два мусульманина, граждане Ирака, которые были обвинены в убийстве двух британских солдат, вторгнувшихся в Ирак в 2003 г. В своей жалобе они ссылались на риск быть наказанными через повешение. Суд постановил, что смертную казнь, приводимую в исполнение органами государственной власти как преднамеренное и умышленное лишение жизни, причиняющее физическую боль и страдания, необходимо квалифицировать как бесчеловечное и унижающее достоинство обращение, которое противоречит статье 3.

Еще во время создания Конвенции смертная казнь как высшая мера наказания не нарушала международных стандартов. Спустя некоторое время наметилась тенденция к ее отмене, затем начали разрабатываться два протокола. При этом суд, исходя из особенностей разработки Протокола № 6 и Протокола № 13, а также практики государств-сторон по вопросу применения смертной казни, все менее склонен считать смертную казнь допустимым исключением из действия нормы о праве на жизнь. 
Суд напоминает, что Конвенция является живым инструментом, который должен толковаться в свете современных условий, и что все более высокие стандарты, которых требует защита прав человека и основных свобод, соответственно, неизбежно требуют и большей твердости в деле критического анализа нарушений фундаментальных ценностей демократического общества (Selmouni v. France, 25803/94, §101, ECHR 1999-V [6]). Он напоминает, что при оценке того, следует ли рассматривать данное обращение или наказание как бесчеловечное или унижающее достоинство для целей статьи 3, суд не может не испытывать влияния изменений в сфере уголовно-исполнительной политики государств - членов Совета Европы и общепринятых стандартов в этой области. Кроме того, понятия бесчеловечного и унижающего достоинство обращения и наказания претерпели значительные изменения не только с момента вступления Конвенции в силу в 1953 г., но и фактически с момента принятия решения суда по делу Soering, 14038/88, 7 июля 1989 г. [7].

Риск быть приговоренным к смертной казни был описан в деле Bader and Kanbor v. Sweden, № 13284/04, 2004 г. [8]. Семья из Сирии обратилась к властям Швеции с просьбой о предоставлении статуса беженца. Отцу семьи из четырех человек была назначена смертная казнь за соучастие в убийстве. В случае возвращения его в Сирию существовал риск быть казненным. Суд посчитал, что, поскольку смертные приговоры приводятся в исполнение в отсутствие общественного контроля и подотчетности, все обстоятельства по поводу исполнения смертного приговора нанесли бы заявителю беспокойство и сильный страх. В силу полного отрицания прав обвиняемой стороны, поверхностного расследования, данное дело представляет собой пример нарушения права на справедливый суд. Если бы семья из Сирии вернулась на родину, она бы испытала страх и ужас за их будущее, и в случае их депортации были бы нарушены статьи 2 и 3.

Суд также отмечает, что за период после принятия решения по делу Soering v. the United Kingdom, 14038/88 от 7 июля 1989 г. [9] правовая позиция в отношении смертной казни претерпела значительную эволюцию. Отмеченная в рамках этого дела фрактическая отмена смертной казни в двадцати двух договаривающихся государствах в 1989 г. постепенно привела к ее юридической отмене в сорока трех из сорока четырех договаривающихся государств и мораторию в последнем (среди договаривающихся) государстве, пока не отменившем казнь, - в России. Этот почти полный отказ от смертной казни в мирное время в Европе находит свое отражение в том, что все договаривающиеся государства подписали Протокол № 6 и сорок одно государство ратифицировало его, т. е. все, за исключением Армении и России. Отразилось это и в политике Совета Европы, который требует от новых государств-членов принятия обязательства по отмене смертной казни в качестве условия их пребывания в организации. В результате этих изменений территория государств - членов Совета Европы стала зоной, свободной от смертной казни.

Столь заметный прогресс сегодня можно считать признаком согласия договаривающихся государств с необходимостью отмены или, по крайней мере, изменения второго предложения статьи 2 (1). Остается открытым вопрос о том, необходимо ли дожидаться ратификации Протокола № 6 тремя оставшимися государствами, чтобы считать, что изъятие из нормы о запрете смертной казни, присутствующее в статье 2 (1), теперь существенным образом изменено.

Часто заявители сталкиваются с жестоким обращением государственных сотрудников, которые могут привести к смерти, но, исходя из практики, суд не находит нарушения статьи 2 и квалифицирует по статье 3 Европейской конвенции. Как было сказано ранее, существует необходимость в признании действий и сил абсолютно допустимыми, т. е. они должны строго соответствовать достигнутым целям.

В деле Andronicou and Constantinou v. Cyprus, 86/1996/705/897, 9 октября 1997 г. [10] полиция вела переговоры с мужчиной, который удерживал свою сожительницу в качестве заложницы. В случае если полиция решит открыть дверь их квартиры, мужчина обещал пристрелить женщину. В итоге полиция с помощью специальных отрядов ворвалась в квартиру, и мужчина направил огонь на сотрудника полиции, в свою очередь полиция выпустила 29 пуль в обоих. Суд счел, что действия сотрудников полиции были абсолютно допустимыми.

Встает вопрос о качестве организации и контроля оперативных действий, приведших к смерти. В деле Ergi v. Turkey, 40/1993/435/514, 28 июля 1998 г. [11] на юго-востоке Турции полиция решила арестовать членов террористической организации. Для этой цели полиция открыла огонь в террористов, в ходе которого были убиты сестра и дочь сестры заявителя. Суд не пришел к решению о нарушении статьи 2 и исходил из того, что полиция действовала согласно инструкции по применению силы и огня. Следовательно, применение силы и действия полиции и других специализированных отрядов должны быть основаны на полной уверенности в благих целях.

С учетом столь единообразной практики можно утверждать, что смертная казнь в мирное время стала рассматриваться как неприемлемая форма наказания, которая уже не является допустимой по смыслу статьи 2. Остальные исключения предусмотрены пунктами а - с части 2 статьи 2. Данные исключения являются исчерпывающими и могут являться допустимыми лишь в случае признания их судом «не менее чем абсолютно допустимыми». Жалобы, которые были направлены в суд по статье 2, в основном касались причинения смерти в ходе борьбы с терроризмом. 


\section{Ссылки:}

1. Смертные приговоры и казни в 2015 году [Электронный ресурc]. URL: http://amnesty.org.ru/pdf/DP_2015_final_ru.pdf (дата обращения: 26.02.2017)

2. Öcalan v. Turkey, 46221/99, 2005, May 12. [Электронный ресypc]. URL: http://hudoc.echr.coe.int/eng\#\{"appno":["46221/99"],"itemid":["001-69022"]\} (дата обращения: 26.02.2017).

3. Ibid.

4. Soering v. the United Kingdom, 14038/88, 1989, July 7 [Электронный pecypc]. URL: http://www.uio.no/studier/emner/jus/jus/JUR5710/h10/undervisningsmateriale/5nov_Soering-v-UK.pdf (дата обращения: 26.02.2017).

5. Al-Saadoon $и$ Mufdhi v. the United Kingdom, 61498/08, 2010, March 2 [Электронный ресурc]. URL: http://www.bailii.org/eu/cases/ECHR/2010/282.html (дата обращения: 26.02.2017).

6. Selmouni v. France [GC], 25803/94, §101, ECHR 1999-V, July 28 [Электронный pecypc]. URL: http://www.hrcr.org/safrica/dignity/Selmouni.html (дата обращения: 26.02.2017).

7. Soering v. the United Kingdom.

8. Bader and Kanbor v. Sweden, 13284/04, 2005, Nov. 8 [Электронный pecypc]. URL: http://hudoc.echr.coe.int/eng\#\{"appno":["13284/04"],"itemid":["001-70841"]\} (дата обращения: 26.02.2017).

9. Soering v. the United Kingdom.

10. Andronicou and Constantinou v. Cyprus, 86/1996/705/897, 1997, October 9 [Электронный pecypc]. URL: http://www.hrcr.org/safrica/life/andronicou_cyprus.html (дата обращения: 01.05.2017)

11. Ergi v. Turkey, 40/1993/435/514, 1998, July 28 [Электронный pecypc]. URL: http://www.refworld.org/docid/3ae6b6291c.html (дата обращения: 26.02.2017)

\section{References:}

Al-Saadoon and Mufdhi v. the United Kingdom, 61498/08 2010, March 2, viewed 26 February 2017, <http://www.bailii.org/eu/cases/ECHR/2010/282.html>

Andronicou and Constantinou v. Cyprus, 86/1996/705/897 1997, October 9, viewed 01 May 2017, <http://www.hrcr.org/safrica/life/andronicou_cyprus.html>.

Bader and Kanbor v. Sweden, 13284/04 2005, November 8, viewed 26 February 2017, <http://hudoc.echr.coe.int/eng\#\{"appno":["13284/04"],"itemid":["001-70841"]\}>.

Ergi v. Turkey, 40/1993/435/514 1998, July 28, viewed 26 February 2017, <http://www.refworld.org/docid/3ae6b6291c.html>.

Öcalan v. Turkey, 46221/99 2005, May 12, viewed 26 February 2017, <http://hudoc.echr.coe.int/eng\#\{"appno":["46221/99"],"itemid":["001-69022"]\}>.

Selmouni v. France [GC], 25803/94, §101, ECHR 1999-V 1999, July 28, viewed 26 February 2017, <http://www.hrcr.org/safrica/dignity/Selmouni.html>.

Soering $v$. the United Kingdom, 14038/88 1989, July 7, viewed 26 February 2017, <http://www.uio.no/studier/emner/jus/jus/JUR5710/h10/undervisningsmateriale/5nov_Soering-v-UK.pdf>. 